\title{
nature
}

\section{Seedless in Seattle?}

When negotiators gather in Seattle this weekend for the ministerial meeting of the World Trade Organization, the future of genetically modified crops will be high on their agenda.

$\mathrm{T}$ he deliberations of the World Trade Organization (WTO), in the context of the global economy, carry far more weight than the legislative bodies of many sovereign governments. The path that the organization chooses at Seattle will therefore play a major part in determining the international viability of transgenic technology. Government representatives and others attending the WTO's third biennial ministerial meeting will be under pressure to handle the issue with extreme care, aware that differences between the United States and Europe could easily spark a damaging trade war. But the WTO meeting will feature divisions not just between the United States and Europe, but between rich and poor nations.

There are two areas of negotiation at Seattle where the interests of rich and poor nations are set to clash. The first concerns a proposal, originally put forward by Canada and Japan, to establish a 'working party' at the WTO expressly to deal with biotechnology issues. The casual observer might ask, who could possibly object? We all admire work and like parties, and deferring a thorny problem for further study never did anyone any harm.

In this case, however, developing countries are viewing the working party with considerable suspicion. Because the WTO has become so powerful, some fear that its formal involvement in the question of agricultural biotechnology could undermine other international agreements - such as any biosafety protocol that may one day be negotiated under the Convention on Biological Diversity - that are potentially more sensitive to environmental concerns.

The biodiversity convention carries at least the potential of helping developing countries to conserve and exploit their substantial biological resources. They are understandably concerned that WTO involvement will lead to environmental considerations being swamped by those of trade. The remit of any WTO group dealing with agricultural biotechnology must therefore be carefully circum- scribed, at the very least. Free trade, whatever certain economists, politicians and professional trade negotiators at the WTO may believe, is not more important than the future of life on our planet.

The second source of North-South friction concerns the future of the Trade Related Intellectual Property Rights (TRIPs) agreement, as it applies to the patenting of plants and animals. TRIPs tries to globalize the type of intellectual property rights regime that protects innovation in the United States and Europe. The fine print of the agreement gives signatories until the end of this year to review a clause allowing a partial exemption for plants and animals.

At Seattle, the United States will be trying to maintain the status quo, while ensuring that the exemption is implemented in a way that allows substantive protection of genetic modifications of both types of organisms. But many developing countries want to expand the clause to bar the patenting of all forms of life. Next year, the whole TRIPs agreement is up for review, and developing countries will seek to revise what they view as its exploitative aspects.

The genes and methods behind agricultural biotechnology are already caught in a web of patent protection that affects the ability of researchers in developing countries to deliver the technology to poor farmers (see Briefing, pages 341-345). The Seattle meeting will be besieged by tens of thousands of demonstrators protesting against the entire negotiation as an affront to the world's poor, and heavily lobbied by agribusiness interests, pushing for open markets and tough controls of intellectual property rights. The best that can be hoped for in Seattle is a compromise deal, establishing a trading regime that will allow genetically modified food seed to enter markets at a pace acceptable to consumers, and plant breeders in developing countries to work with transgenic crop technology at an affordable cost. Even this modest goal, however, would be a substantial achievement in the current, highly charged atmosphere.

\section{A bioethics dilemma for Germany}

Debates on the ethics of biomedical research must find a way to combine breadth of vision with a practical timescale.

A t first glance, the backtracking of Germany's Social Democrat Party on a pre-election promise to support an inquiry into the social impact of modern genetics and biomedicine (see page 331) seems perverse. Similar inquiries by comparable bodies in other countries have been successful in using focused debate, backed by careful research, to forge a workable consensus on such contentious topics. And the proposed procedure - a so-called Enquete Commission — was designed specifically for such a task.

But the experience of such inquiries in Germany has been mixed. Some, such as one into genetic engineering in the mid-1980s, have been successful, while others - for example, into technology assessment - have not. As the latter showed, the specific form of debate encouraged, however democratic in principle and practice, can fail to mesh with a practical timescale. Where issues are pressing, or where - as in the case of the implementation of the Council of Europe's Declaration on Human Rights and Biomedicine - other European states are setting the pace, an open-ended debate intended to achieve a conclusion through reasoned discussion alone can be an unrealistic strategy.

To that extent, the Social Democrats, their members in the government, and other political parties, are right to explore more practical alternatives. One is to create a national bioethics advisory council with broad responsibilities to monitor specific bioethical issues as these arise, for example through the activitities of targeted working groups. Another would be to explore the 'consensus conference' model, allowing non-experts to form judgements based on a critical review of the evidence.

At the same time, however, it would be short-sighted if any alternative to the commission was to be so narrowly focused as to lose sight of the broader perspective. In that sense, the Greens, despite their overly romantic, anti-technology stance, are right: whatever it's faults, an Enquete Commission allows for a range of views to be discussed with a breadth and seriousness appropriate to the significance of the topics under debate. This must not be lost. 